Viso - Cadernos de estética aplicada Revista eletrônica de estética

ISSN 1981-4062

$N^{\circ} 22$, jan-jun/2018

http://www.revistaviso.com.br/

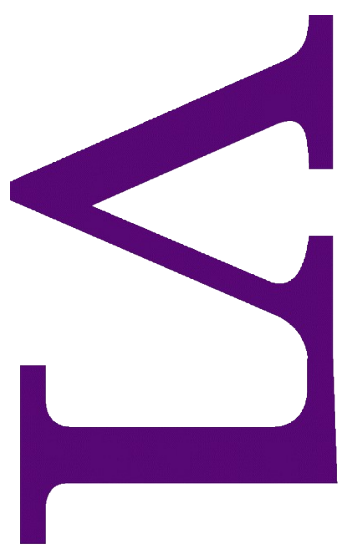

N

o

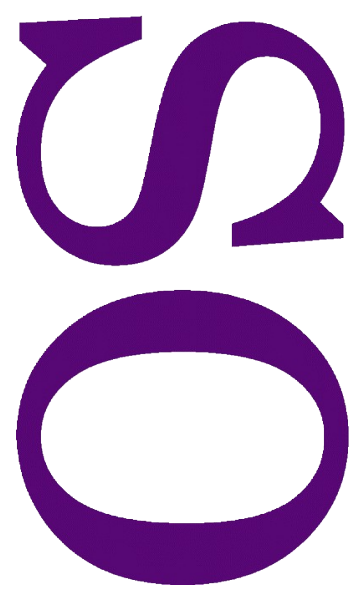

\title{
A Medeia de Pasolini e a tragédia do homem ocidental Alexandre Costa
}




\section{RESUMO}

\section{A Medeia de Pasolini e a tragédia do homem ocidental}

Sentindo-se repudiada por Jasão, que decide esposar a filha do rei Creonte, Medeia dá início à sua vingança, conseguindo, por meio de seus dons extraordinários, que o Rei e a sua filha morram queimados, para depois matar os seus próprios filhos, de quem Jasão é pai. Contando com a exuberante presença de Maria Callas, a versão de Pasolini para Medeia, de Eurípides, mostra o seu toque pessoal ao sublinhar o confronto entre Medeia e Jasão como figuras de dois mundos incompatíveis, realizando uma leitura literalmente histórica da peça. Ela representa um mundo arcaico e divino, marcado pelo mote "tudo é sagrado"; ele, o herói atual, pragmático, racional e dessacralizado - sua tragédia é também a origem da tragédia do homem contemporâneo.

Palavras-chave: Medeia - Pasolini - Eurípides - tragédia - crítica da cultura

\section{ABSTRACT}

\section{Pasolini's Medea and the Tragedy of Western Man}

Feeling repudiated by Jason, who decides to marry King Creon's daughter, Medea begins her vengeance, accomplishing, by means of her extraordinary gifts, that the King and his daughter are burned to death, later killing her own children, of whom Jason is father. With the exuberant presence of Maria Callas, Pasolini's version of Euripides' Medea shows his personal touch by emphasizing the confrontation between Medea and Jason as figures of two incompatible worlds, performing a literally historical reading of the play. She represents an archaic and divine world, marked by the motto "all is sacred"; he, the current, pragmatic, rational, and desacralized hero - his tragedy is also the origin of the tragedy of contemporary man.

Keywords: Medea - Pasolini - Euripides - Tragedy - Critique of culture 
COSTA, A. "A Medeia de Pasolini e a tragédia do homem ocidental". In: Viso: Cadernos de estética aplicada, v. XII, n. 22 (jan-jun/2018), pp. 15-35.

DOI: $10.22409 / 1981-4062 / v 22 i / 237$

Aprovado: 29.05.2018. Publicado: 30.06.2018.

(C) 2018 Alexandre Costa. Esse documento é distribuído nos termos da licença Creative Commons Atribuição-NãoComercial 4.0 Internacional (CC-BY-NC), que permite, exceto para fins comerciais, copiar e redistribuir o material em qualquer formato ou meio, bem como remixá-lo, transformá-lo ou criar a partir dele, desde que seja dado o devido crédito e indicada a licença sob a qual ele foi originalmente publicado.

Licença: http://creativecommons.org/licenses/by-nc/4.0/deed.pt_BR

Accepted: 29.05.2018. Published: 30.06.2018.

(C) 2018 Alexandre Costa. This document is distributed under the terms of a Creative Commons Attribution-NonCommercial 4.0 International license (CC-BY-NC) which allows, except for commercial purposes, to copy and redistribute the material in any medium or format and to remix, transform, and build upon the material, provided the original work is properly cited and states its license.

License: http://creativecommons.org/licenses/by-nc/4.0/ 
Completamente iluminada, a Terra resplandece sob o signo do infortúnio triunfal. O processo civilizatório, no qual o homem aprendeu a controlar a natureza em seu próprio benefício, acabou resultando no seu contrário, a mais crassa barbárie, em virtude da unilateralidade com que foi conduzido desde a Idade da Pedra até nossos dias.

(Theodor Adorno e Max Horkheimer ${ }^{1}$ )

Ao longo de sua trajetória como cineasta, Pasolini dedicou-se à adaptação de duas tragédias gregas, Édipo Rei (427 a.C.), de Sófocles, e Medeia (431 a.C.), de Eurípides, de que resultaram dois dos seus filmes mais celebrados, para os quais conservou o mesmo nome das obras originais. ${ }^{2}$ No caso de ambos, a pergunta que se impõe de imediato, consideradas, inclusive, as atuações de Pasolini como poeta, escritor e ativista político, é: o que um artista e pensador contemporâneo como ele buscava na tragédia grega? Trata-se, naturalmente, de uma pergunta-chave não só para a análise dos filmes aqui mencionados, mas também para uma interpretação da sua obra como um todo, uma vez que questiona diretamente pelo sentido e pela proposta que levam - ou mesmo obrigam - o autor a visitar obras tão primevas e fundadoras da cultura e da história do Ocidente. Pelo mesmo motivo, será também esta pergunta que norteará as pretensões reflexivas deste ensaio, favorecendo concretamente a exploração de uma série de temas centrais que reconheço como elementos comuns aos dois filmes; elementos que, por fim, serão os reveladores das motivações decisivas e irrecusáveis do autor em sua visita e diálogo com o teatro e a cultura trágica dos antigos gregos.

O principal elemento de identidade que une não apenas os dois filmes em questão, mas também as obras originais que lhes servem de base, diz respeito ao processo civilizatório descrito pela história do Ocidente e às potências seminais que o condicionam e motivam. Deste modo, ambas as peças oferecem um terreno propício para quem, junto a elas, tem interesse em perguntar quais foram os rumos tomados por esse processo; de que elementos prévios ele dependeu para o seu próprio desenvolvimento; que decisões e acontecimentos marcaram seus desdobramentos e o tornaram possível. É este o caso de Pasolini. Mais do que isso, o autor formulará essas perguntas criticamente, como quem impõe um olhar retroativo a essa história, fazendo ver, de forma incisiva, com que custos e sob que efeitos toda essa fome civilizatória se desenrolou: lavrada a preço da força e da violência, bem como da segregação das alteridades que the pudessem supostamente deter o caminho, Pasolini envereda a sua câmera e a sua perspectiva na direção e sob o ângulo de quem quer e sabe mostrar quais foram e quais são os sacrifícios e os sacrificados que saciam o furor dessa gula e de seu especial apetite por "progresso".

Nesses termos, ainda que Édipo Rei, de Sófocles, seja uma tragédia em que tais pulsões seminais se oferecem à fartura ao olhar crítico e contemporâneo do autor, Medeia, de Eurípides, parece ocupar um lugar todo especial neste âmbito de questionamento: diante dela, não será sequer preciso a distância do olhar de um contemporâneo para que 
aquelas questões acima arroladas sejam pronunciadas, uma vez que o texto original as impõe com veemência. O mais estarrecedor em Medeia, sentirá Pasolini, é que essas mesmas perguntas que o motivam a visitar a tragédia grega já haviam sido elaboradas pela própria tragédia grega. Ou melhor: por esta tragédia grega, por esta peça escrita e apresentada por Eurípides em 431 a.C. Convém sublinhar, primeiramente, que já se havia aberto a Eurípides, um poeta trágico, a perspectiva de que o período clássico da cultura grega, tal como o denominamos hoje, já tinha despendido recursos, força e artifícios que promoveram inovações tais que elas mesmas impunham, ao seu próprio passado, uma radical e violenta transformação. Essa realidade histórica, inscrita e escrita em delicada ambiguidade, como de hábito na poesia trágica, mostra nitidamente que aquilo que para uns significa transformar, evoluir e progredir, significa, para outros, aniquilação e morte: trata-se da história devorando a própria história, tal como no (esquecido) mito de Cronos, ironicamente um desses vencidos. Trata-se, portanto, de lembrar e acusar que o ato e o impulso de civilizar é também e a um só tempo a própria ação de barbarizar: criando e impondo a ideia de Civilização como o ideal de sua destinação histórica, o Ocidente cria também a Barbárie; sua almejada distinção como "homem civilizado"3 exige dele mesmo a efusiva produção de bárbaros. Trata-se da dialética fundamental do projeto civilizatório: civilizar e barbarizar são o mesmo. ${ }^{4}$

Esse teor de pensamento e essa visão em perspectiva são os elementos que unem de imediato Pasolini a Eurípides, ou, ainda mais especificamente, que unem Pasolini à sua Medeia. Não se trata, portanto, de um autor que se vê movido pela intenção de recriar a tragédia de Eurípides, da qual o filme é formalmente adaptação, apenas para retratá-la historicamente ou para fazer dela uma bela composição cinematográfica do que seja ou tenha sido a Medeia de Eurípides originalmente. O que Pasolini ambiciona com esse diálogo consiste, antes de tudo, em "abusar" da peça para poder continuar falando, não tanto dela, a peça de Eurípides, mas a partir dela sobre esses mesmos aspectos que a obra original já acusava: é preciso transcriá-la, reinventá-la a ponto de torná-la sua; só assim é possível dar continuidade e expansão à própria crítica euripideana e apontar, consequentemente, qual o alcance e que enorme extensão esse projeto civilizatório angariou para si, estes mesmos projeto e processo que, nas páginas de Eurípides, encontravam-se talvez no curioso e delicado momento histórico em que se fundam e consolidam, mas no qual também são, possivelmente, embrionários e certamente imperceptíveis à maioria dos seus contemporâneos.

Movido por essa ótica, Pasolini não desejaria e nem teria como trazer essa peça às telas de cinema se não fosse por intermédio de um grande grau de intervenção de sua parte sobre a obra original, respeitando-a na exata medida em que a "desrespeita", não the sendo fiel como quem quisesse ter dela apenas um retrato, nem the sendo submisso como se quisesse meramente ilustrá-la em imagem cinematográfica. Pasolini não realiza, portanto, uma adaptação formal da peça de Eurípides: ele a recria tão radicalmente que o seu enredo original sequer se torna inteligível ao espectador. É bem provável, por sinal, que essa "ininteligibilidade" tenha sido voluntariamente adotada como 
um dos recursos estéticos da obra, uma vez que aquilo que Pasolini vai apresentar de mais conceitual e mais decisivo neste seu filme consiste em revelar como nós não mais reconhecemos a voz dos antigos mitos, como nós nos tornamos paradoxalmente elos perdidos do nosso próprio berço cultural primeiro, de onde decorre, dentre tantas outras consequências, não termos em geral mais nenhum acesso ao trágico e à sua poesia. Essas impotência e perda efetivam-se justamente porque nos tornamos histórica e paulatinamente seres diabolicamente ${ }^{5}$ racionais, (quase) completamente explicativos e munidos de argumentos, com que nos iludimos das mais várias ilusões, inclusive a de desmitificar a natureza, domando-a, submetendo-a ao nosso pretenso poderio. ${ }^{6}$ Portanto, diante de tal disposição crítica, ter de explicar a história a seu público, expondo didaticamente o enredo da Medeia original, já seria trair um dos conceitos que fundamentam o filme.

O diálogo de Pasolini com a tragédia de Eurípides realiza-se portanto a partir de uma apropriação explícita da obra original, incidindo-Ihe um corte que extrai dela aquele elemento que mais Ihe interessa mostrar e amplificar: o surgimento e o progresso contínuo de um modo de pensamento e de linguagem que, exigindo e configurando toda uma outra e nova concepção de mundo, fez ruir e soterrou nosso passado mais primevo, em que a poesia e seu encanto, em que a alegoria e seu possível delírio, a desrazão e a força do símbolo é que detinham o poder da palavra e mediavam, assim, nossas relações com o mundo e a natureza: é para falar da nossa surdez em relação a esse passado e a essa linguagem e também sobre como foram calados, a ponto de não mais podermos senti-los ou compreendê-los efetivamente, que Pasolini filmou a sua Medeia. Trata-se do momento histórico em que ocorre uma irreversível ruptura entre o homem antigo, morto para sempre, e que jamais poderemos ser, e o homem "moderno", aquele que, na despedida dessa primeira era, inicia e prossegue sua história, estendendo-a até estes nossos dias. Mirando-se frente a frente, esses dois homens não se reconhecem: é esta a mais emblemática e decisiva imagem do filme ${ }^{7}$, alusiva, igualmente, à sua própria pretensão como obra: a de nos oferecer um espelho nosso, primordial, em que estranhamente já não nos reconhecemos mais.

É importante notar que acusar essa surdez e essa ruptura poderia resultar apenas numa observação histórica, revelando uma determinada compreensão acerca da história de um homem ocidental que teria se diversificado de tal modo a ponto de em nada reconhecer a sua origem. Tratar-se-ia, neste caso, de uma visão já agudamente crítica, talvez precisa, talvez questionável, e certamente discutível, como qualquer outra. Mas Pasolini vai além: ele empresta ao filme, inegavelmente, um certo tom de nostalgia. Ele lamenta essa surdez. Porque ele certamente poderia dizer e mostrar por suas imagens tão somente a percepção de que, na sedimentação do tempo histórico, os séculos passaram e com eles alterou-se a estrutura do pensamento e da linguagem, e a partir disso alteraram-se também os hábitos, o comportamento e a concepção de vida; poderia o filme ter se detido na percepção de que o homem é um animal que se altera na história e pela história, e que esse homem, esse homem antigo, que é uma mulher, que é 
Medeia, este homem se perdeu. Mas Pasolini lamenta essa perda. É a posição de um artista, de um intelectual, a quem não convém não tomar partido, a quem não seduz o devaneio da (impossível) neutralidade, falácia maior de uma tradição de pensamento que se orientou sempre mais e mais em prol do positivo e a favor de uma pretensa objetividade que Ihe revelaria, acerca de todas as coisas, "a verdade nua e crua", livre de toda crendice - como explicitamente postulará o lluminismo, por exemplo -, como se não fosse igualmente crendice reivindicar a imparcialidade de verdades puramente objetivas, caminho em geral sempre ainda muito caro às ciências. Isto sim, dirá Pasolini, é um delírio e uma insanidade. Por isso mesmo, bem mais do que identificar essa perda e essa surdez tal como aqui mencionadas, ele quer impor uma crise a essa condição. É por isso que insiste em usar do nosso contraste para com o homem antigo e sua poesia: adota-o como artifício para acuar o homem atual contra si mesmo - é preciso fazer com que ele pense seus passos e o sentido, sempre continuamente avolumado, das direções e decisões históricas que tomou.

Este mundo perdido e estilhaçado, irrecuperável e mesmo irreconhecível, é o mundo de Medeia. O outro, que se sobrepõe a ele, o de Jasão. Ambos estão unidos de alguma forma, mas nunca por inteiro. É um casamento que nunca se cumpre plenamente, ainda que com filhos, mas filhos a serem mortos, sacrificados. E quando Jasão decide casar, escolhe outra. O pacto com Medeia fracassa por ser traído. É uma metáfora absolutamente potente, a de Eurípides, e que Pasolini pretende dilatar ainda mais. Medeia e Jasão são personagens que espelham um tenso antagonismo, um antagonismo em que se inscreve uma complexa dinâmica de continuidade e descontinuidade: eles são personagens contínuos, que se tocam, (quase) casam e têm filhos porque se encontram e coexistem no tempo histórico de suas ações; e são, ao mesmo tempo, terrivelmente descontínuos, porque o sentido desse encontro é justamente o desencontro de suas realidades, cada vez mais afastadas no próprio progresso do tempo, no devir do processo histórico que acaba por provocar a sua mais radical descontinuidade. É este então o momento da fissura e da ruptura histórica, o da despedida e morte do homem antigo, representado pelo feminino que é Medeia, e do predomínio do homem "moderno", representado pelo masculino que é Jasão. É também o momento especular da separação e do casamento não cumprido, da traição e da quebra do pacto, ao que sucede o sacrifício dos próprios filhos por parte de Medeia. Já não haverá mais frutos dessa continuidade, pois seu último elo possível foi desfeito; sua aliança, partida. É o momento da metáfora máxima para o rumo histórico do homem ocidental, o momento em que Jasão decide abandonar Medeia. E como toda decisão é uma cisão, trata-se do momento em que Jasão cinde por inteiro com o mundo, a cultura, os valores e a história que Medeia representa.

Jasão e Medeia são personagens criados para que a sua luz apareça apenas e tão somente por contraste: eles configuram uma tensão, polarizando extremos que se divorciam ao longo do tempo, revelando o sentido histórico entre o que será ultrapassado e posto de lado - combatido e marginalizado até o seu desejável desaparecimento - e o 
que se quer seu sucessor, seu "civilizador", pretendendo-se simultaneamente presente e futuro histórico de toda uma tradição. Medeia e Jasão polarizam, respectivamente, as históricas tensões entre o sagrado e o profano; o arcaico e o "moderno"; o tempo cíclico e o tempo linear do progresso; a poesia e a lógica; a fêmea e o macho; o feminino e o masculino; o matriarcado e o patriarcado; a naturalidade do divino, que resulta numa poética do mundo, cujas palavras míticas lhe impõem o encanto e a fantasia, e a naturalidade da natureza, em que esta se desmitifica diante de argumentos e razões, ganhando em ciência, mas perdendo sua magia e seu encanto. A lógica histórica dessa relação literalmente extremada é o da asfixia e exclusão do primeiro dos seus pólos, o pólo Medeia, em favor do incremento contínuo do pólo Jasão.

À lente de Pasolini interessa ampliar as já claras oposições que Medeia e Jasão representam, precisamente a fim de ajustar a magnitude dessa oposição que, em sua ótica, apenas se radicalizou no decurso dos mais de dois mil e quatrocentos anos que nos separam da tragédia de Eurípides. Pasolini não esconde a sua simpatia por esse mundo e por esse tempo que desmoronam gradual mas violentamente ao longo da história. As intervenções e acréscimos que impõe à obra original na construção do seu filme atendem a esse desejo de ampliação e à necessidade de delinear firmemente o seu posicionamento crítico em relação a esse progresso histórico que a ele, Pasolini, mais parecerá um retrocesso do que uma "evolução". O inegável tom nostálgico que matiza o filme, por exemplo, é um dos recursos através dos quais o autor refere que a perda desse mundo arcaico, mundo de Medeia, é também a perda de um mundo encantado. E quando se fala na perda de um mundo pretensamente encantado é preciso entender que esse homem, Jasão, que sucedeu a esse mundo, operou de algum modo uma transformação de pensamento e de linguagem através da qual o mundo inteiro aparecerá ante seus olhos como detentor de novas e outras imagens. Estas imagens, porém, nascem do desmanche e do desarme daquelas invenções, hábitos e cultos com que aquele homem antigo, poético, ornava a sua vista e que, por isso mesmo, podia ver nesse mundo o espelho da sua fantasia, da sua criação e do seu engenho inventivo. Essa linguagem, a que pertence a narrativa mítica originária de todos os povos, cede lugar para uma forma e modo de discurso marcados por uma racionalidade sempre crescente $^{8}$, por um pensamento cujo teor e poder dialético-diabólico fizeram com que se apagassem historicamente os antigos deuses, deuses de Medeia, fazendo calar suas vozes. Isto é, de fato, um feito histórico, ou alguém hoje, por exemplo, ofereceria algum culto a Zeus por maior Ihe fosse a simpatia pelos antigos gregos?

Para Pasolini, este mundo novo, mundo marcado pelo apogeu de Jasão, só ganha em desencanto. É um mundo pobre senão vazio de magia. Pensemos: quem é Medeia, afinal? Ela é a senhora dos sortilégios e dos feitiços. Ela manipula tudo, seu poder e sua arte estão nas suas mãos. É de "mão" e "manipular" que derivam originalmente os termos "magia" e "magistral". Que truques essa mulher pode, com suas mãos, que nós não podemos mais? Por que essa personagem, Medeia, nos é estranha, possivelmente agressiva e, para muitos, talvez até mesmo de insuportável repugnância? Sabemos que 
o público à época não gostou nada da provocação de Eurípides. Porque ele já está acusando, com esta peça, que existia uma "região" de língua e origem gregas, uma extremidade do mundo helênico, que guardava sempre ainda o frescor de uma tradição arcaica, já suficientemente exótica e estranha ao grego ático e, por extensão, ao público ateniense que assistiu à peça, a ponto de lhe parecer selvagem e incivilizada. O próprio idioma, arcaízado, começa a não ser mais compreendido pelos demais helenos e, claro, serão os "arcaicos" que serão repreendidos por não mais falar grego. Por que não o contrário?

Eurípides escolhe a dedo uma personagem que habita originalmente esses confins do mundo grego, Medeia ${ }^{9}$, habitante da Cólquida, atual Georgia, uma das repúblicas da extinta União Soviética. O que hoje denominamos ser a antiga Grécia refere-se a uma identidade linguística; o mundo grego sempre foi o mundo de expressão grega, o mundo de uma língua, não de um Estado ou de qualquer outro critério de unidade que não o idiomático. Não ter o idioma reconhecido como grego significa automaticamente a perda da identidade helênica, significa não ser grego. E não ser grego, por sua vez, significa ser bárbaro. Eurípides escolhe com precisão uma grega que está na fronteira do bárbaro, ironicamente, talvez, por falar e cultuar um idioma grego tão original e arcaico que não mais reconhecido. Sua voz, bem como seu idioma, soam estranhos, estrangeiros, bárbaros. É interessante notar a etimologia da palavra "bárbaro", que deixa exposta com radical clareza que a identidade dos helenos é uma identidade linguística, já que o bárbaro é aquele que fala um bar bar bar incompreensível: não falou grego, é bár-ba-ro. E como uma identidade linguística é também identidade de crenças, cultos, valores e normas, toda a construção da identidade do povo que é berço e origem do Ocidente fez-se por um artifício negativo e de exclusão: o bárbaro é o não-grego.

Este elemento é importantíssimo para a compreensão da tamanha extroversão que o Ocidente demonstrou em sua história, marcada pelo movimento de invasão, aculturamento e colonização de outros povos. Sua identidade vem a ser afirmada na mesma intensa medida com que nega as dos demais, investindo, atirando-se contra elas; seu ser não-bárbaro exige negá-lo, e negar o bárbaro exige, por sua vez, civilizá-lo, matando-o, seja literalmente, seja convertendo-o à força a padrões ocidentais de cultura. Eis o preço de civilizar. É a isso exatamente que se refere o projeto civilizatório promovido pelo Ocidente, projeto em franca marcha, adotando hoje eufêmicos nomes, tal como, por exemplo, "globalização", para traduzir - e também dissimular - o mesmo impulso civilizacional de sempre, outras vezes batizado como Cruzadas, Inquisição, Expansão Ultramarina, Revolução Industrial e, mais recentemente, a pretensão expansionista e totalitária de um Terceiro Reich e a lógica colonizatória tão própria e característica à Guerra Fria. Em todos esses movimentos, ainda que claramente distintos entre si, subsiste contudo a identidade de um projeto de conversão de todo o mundo ao Ocidente por meio da violência dos seus meios: o incremento obsessivo da técnica, por fim sempre instrumentalizado em prol dos avanços bélicos que the possibilitaram e possibilitam o domínio sobre as demais culturas. Para tanto também serviu sua ciência e 
sua razão, eis a face mais cruenta de nosso tão propalado progresso. Eis o império de Jasão, império que se nutre sempre e a cada vez do abandono e morte de Medeia. Notese, agora e portanto, a eloquente e perversa precisão contida no termo "globalização": globalizar é ocidentalizar, reduzindo toda diversidade cultural do Globo a uma única matriz de cultura e de valores que, para ser hegemônica, aniquila todas as demais.

Medeia fala grego, mas ela se encontra nos limites extremos em que se ambiguam civilização e barbárie. Sem que tenha pedido ou chamado, um invasor, Jasão, viaja desde essa Grécia ática, cujo epicentro histórico é Atenas, até a sua terra, a Cólquida, onde ocorre o seu trágico encontro. Eurípides exala a mesma nostalgia que Pasolini intensifica: poeta trágico, homem da religião, uma vez que a tragédia grega veio a ser uma das principais liturgias da antiga religião dos helenos, Eurípides era também amigo de Sócrates e íntimo dos círculos filosóficos de sua época; íntimo, portanto, das novas formas do pensar e do dizer que ali proliferavam como talvez nunca em outra parte qualquer. Desse epicentro grego que se transforma e racionaliza com a filosofia, com o direito e com a retórica, e com toda repercussão política que elas impõem, vai surgindo todo um outro modo de pensar e proceder. Parece que Eurípides, ainda poeta, teme pela perda da tradição poética que o precedeu; talvez tema, mais que tudo, ser ele mesmo um dos fautores dessa ruína, como curiosamente indicará Nietzsche, ladeando-o a Sócrates e a Platão no que tange ao feito de uma Grécia que teria aniquilado toda uma Grécia anterior, arcaica, heróica e trágica. ${ }^{10}$

De qualquer modo, para que o poeta Eurípides visite a ancestralidade dessa poesia, para que ele conheça e reconheça a origem remota da sua própria fala, ele necessita de uma personagem retirada dos confins do mundo grego; para achar uma mulher, que ainda vive segundo o modo de um sagrado ancestral, que ainda manipula a sua magia, teve ele que a buscar nas fronteiras entre o mundo grego e o bárbaro, indicando assim, já no seu tempo e na sua cidade, aquela surdez que, segundo Pasolini, só aumentará com o devir histórico que tanto caracteriza Jasão, o novo homem que somos todos nós. Este homem que escreve e também este que o lê.

É Jasão quem cala a voz de Medeia. E, na arrogância de educá-la, tal como fizeram, por exemplo, os europeus com as populações endógenas das Américas, "civilizando-os", ele apenas consegue desfigurá-la: tanto na peça como no filme, o contato com Jasão corrói Medeia, contamina-a de novos modos e pensamentos a ponto de ela estranhar a si mesma e não se reconhecer, sendo o sintoma maior dessa estranheza ela não ouvir mais a voz do sol, seu avô em linha direta. Ainda que momentaneamente, até Medeia padece dessa surdez. Jasão cala a voz de Medeia e cala também a voz do sol. É ele que pretende, arrogante e convicto de sua própria fala, dizer quem eles são. Jasão não tem mais o que ouvir do sol, só tem a dizer dele, expressando assim o seu conhecimento sobre todas as coisas. ${ }^{11}$ Mas quem é Jasão? Somos todos nós. Este a quem costumamos nomear "homem moderno" e que, abusando um pouco das terminologias consagradas, Eurípides já reconhece em pleno século $V$ a.C. Jasão representa o início 
da história do progresso daquele tipo de pensamento e racionalidade anteriormente aludidos, que vão apagando não só a voz dos deuses, como também promovem por fim a sua morte, o seu desaparecimento.

Mas como se aposentam a voz e o poder disso que valia até então como o poder constitutivo e criador do próprio mundo? Há uma série de questões muito provocativas que fizeram com que a Medeia de 431 a.C, de Eurípides, causasse incômodo e insatisfação no público que assistiu à peça. Primeiro, numa cultura que poderíamos designar, em termos atualmente correntes, como claramente machista, a personagem principal é uma heroína, uma mulher. Essa, aliás, é uma das inovações das quais Eurípides parece ter sido frequentemente acusado pelos seus contemporâneos, a de falar também a partir da perspectiva do feminino. E Medeia talvez seja a sua heroína mais forte, mais selvagem. Ora, ser heroína, num gênero artístico, literário e litúrgico como é a tragédia, significa sempre que esta personagem vai sofrer tormentos incríveis, mas de alguma forma a sua grandeza será exaltada, nem que seja a grandeza da sua desgraça ou, mais do que isso, a grandeza de como a personagem reage e sobrevive a essa desgraça; é preciso ser grande, trata-se do traço principal do heroísmo grego. 0 herói é sempre grandioso de algum modo, é uma questão de medida do próprio herói: nem que seja na desdita, nem que seja na sua loucura, ele tem que ser grande, possibilidade extrema do humano. Este último tipo, aquele que se realiza por algum tipo de engrandecimento em meio aos seus próprios infortúnios, em geral acentuadamente terríveis, é o modo próprio do herói trágico; o modo trágico de fazer-se herói. Imagine-se então aquele público grego, assistindo ao seu teatro, liturgia máxima de sua época, e um dos seus sacerdotes, um de seus poetas, Eurípides, apresenta uma heroína que, como tal, não é alfim punida pelos deuses, a despeito de ser uma mãe que mata os filhos para provocar ciúmes num marido, Jasão, que transgride um pacto de casamento, que quebra a aliança de uma palavra empenhada. Neste contexto, transgredir a lei do casamento é ferir diretamente a palavra dos deuses. Ela acusa Jasão dessa impiedade, questionandoo insistentemente como lhe era possível transgredir a lei ancestral, divina, ignorando a lei de todo sempre em troca do ineditismo das leis e conveniências humanas. Medeia acusa um homem que se autoriza a julgar e a julgar laicamente, um dado claro da origem grega dos nossos tribunais, surgidos precisamente nesta mesma época.

É por tudo isso que é ela a heroína e ele o transgressor. Eurípides e Pasolini mostramnos uma mulher que mata os filhos, mas o seu crime será emoldurado internamente a uma transgressão maior, a de Jasão. Assim sendo, apesar de todas as suas dores e desditas, é Medeia que, como heroína, triunfa ao fim da peça, não sendo punida por seus atos. A provocação é enorme, já que toda forma de homicídio constitui crime para essa mesma religião grega, o que se diria, então, de um infanticídio? Representado ritualmente e pleno de afeto por Pasolini, o sacrifício dos filhos pelas mãos da própria mãe não impõe à Medeia, seja na peça, seja no filme, a condição de criminosa, antes salvaguarda-lhe a condição extrema de heroína, tendo a seu lado a benevolência e a bênção dos deuses que, na figura do sol, ajudam Medeia a fugir, livrando-se das 
ameaças - civis?- e das imprecações de Jasão.

É muito significativo que o deus de quem Medeia é neta seja o sol, uma divindade impessoal, não-humanizada, que se confunde com a própria natureza. O mundo de Medeia é tão remoto que os seus deuses não diferem da carne do mundo. Eles não criaram o mundo, eles são o mundo. Não há distância nem diferença entre divindade e natureza. Não é um o criador e outro a criatura, eles são um mesmo, uma fina e brilhante superfície. É um mundo livre da profundidade da abstração, um mundo à flor da pele e à palma da mão. Na própria tradição poética grega, os deuses antropomórficos, tais como os da segunda geração olímpica, são tardios. Não ocorreu de modo diferente com outras culturas, a naturalidade das divindades míticas sempre foi mais radical quão mais remoto e primevo for o seu momento dentro dessa mesma tradição. A humanização dos deuses é sintoma histórico de um processo de gradual emancipação do homem ante a natureza, processo de paulatina antropomorfização dos deuses e de gradual antropocentrismo, dos quais Jasão é símbolo.

Mas os deuses de Medeia ainda são a própria carne da Terra. São sensíveis e físicos, não espirituais, abstratos ou vagos. Medeia não evoca, à exceção de Zeus uma única vez, nenhum deus que não seja da primeiríssima geração, impessoais e integralmente naturais, como se quisesse apontar que os outros deuses, humanizados, são já uma decadência da religião grega em relação ao seu passado, já é poesia corrompida da sua origem genuinamente sagrada. Em contato com Jasão, homem de outra era, ela "civilizase" aos poucos, ensurdecendo-se para seus antigos deuses. Medeia vai sendo mortificada, e só o fim do casamento, que jamais fora casamento, faz com que a antiga Medeia ressurja e torne a ouvir a voz da terra e do sol. Pasolini mostra com insistência esse processo, ajudado pela memorável atuação de Maria Callas que, nestas cenas, pisa com força os pés sobre a terra e clama furiosa pelos raios solares e seu calor. Quando surda, Medeia diz de si mesma: "sou outra criatura agora, esqueci tudo", ao passo que, desde o início, Jasão tripudia do próprio velo de ouro que fora buscar, declarando: "essa pele não tem nenhum significado". Em seu mundo e sensibilidade, em sua fala e em seu pensamento, já não cabem o arracional, a magia e o encanto que provoca o desconhecido, tecido em fantasia e invenção. Ao lado dele, ela se espanta e indaga "Sol, por que eu não te ouço mais?", "Terra, cadê você, Terra?". Medeia transforma-se pouco a pouco em Jasão, alegoria para toda uma tradição que se perdeu, soterrada pelo edifício da civilização.

Eis a alegoria principal que se resolve no antagonismo entre Jasão e Medeia que tanto interessa a Pasolini. Sendo dois personagens que representam paradigmas da história do Ocidente, um, Medeia, uma mulher que representa esse humano arcaico e original que foi suplantado violentamente na história por esse outro, Jasão, que será o nosso herói moderno, Pasolini encontra entre eles a brecha necessária para alardear que o sentido histórico ainda hoje vigente, o sentido da própria modernidade e da pósmodernidade, a despeito de seus possíveis esforços em contrário, é sempre ainda a 
insistência e pela insistência no esforço pelo progresso, a radicalização desse ser Jasão, a incessante hipertrofia de um mundo desencantado, racionalizado e técnico, instrumentalizado e hostil à natureza, ao prazer e à própria sensibilidade. Para Pasolini, nós somos mais Jasão a cada (não) santo dia. E isso parece ter, para ele, a urgência de uma acusação.

É em nome dessa urgência e dessa crítica que Pasolini acrescerá, em relação à obra de Eurípides, uma série de cenas e textos absolutamente autorais. A mais decisiva delas é um conjunto de três diálogos entre Jasão e Quíron, seu preceptor segundo os antigos mitos. ${ }^{12}$ Nesses diálogos escritos por Pasolini, é como se o próprio diretor abrisse uma janela no seu filme a fim de se apresentar diretamente. No primeiro deles, Jasão conta apenas cinco anos de idade. No segundo, treze. E no último já é um homem adulto. A composição desses diálogos é um verdadeiro exercício de aproximação dessa poesia antiga, da sua fantasia e do seu modo de dizer. Consequentemente, o primeiro deles já revela um hábil emprego de uma narrativa mítica, fantástica, em que, alegoricamente, um menino de cinco anos representa essa infância poética e mágica da humanidade. Vemos aqui Jasão ainda não ser Jasão. Este Jasão, ainda menino, representa agora, simbolicamente e totalmente retirado do contexto da peça, o homem em sua origem mais remota, em que ele vê e pode ver um centauro (um poeta) que o educa, compreendendo e ouvindo a sua voz plena de sentido.

Essa imagem alude ao fato de que Jasão nasceu em meio às entranhas desse mundo antigo que ele mesmo fará desmoronar. Mais uma vez marca-o o signo da traição, a figura do traidor. Mas sim, ele sentiu o cheiro dessa tradição, conviveu com ela, e foi até mesmo criado por um ser divino, fantástico, que é metade besta e metade humano. Jasão somos nós, é o homem ocidental em sua historicidade, ele é criado originalmente por um centauro. Mas quando já possui treze anos, já um pouco afastado dessa infância e origem, o centauro continua a instruí-lo, ele continua a ouvi-lo, mas seu semblante já deixa escapar certo ar de estranheza e incompreensão. Na terceira aparição de Quíron, o centauro já não aparece como centauro: ante um Jasão adulto, finalmente feito, Pasolini, falando por imagens, faz Quíron aparecer sem sua parte animal, sem sua porção cavalo. Quando esse homem se torna adulto - porque ele se crê superior a essa criança do passado - , ele já não vê centauros por aí, muito menos há de dar ouvido a eles. Então o centauro-não-mais-centauro adverte Jasão (mas para quê? Se ele já não consegue ouvi-lo?), ironicamente:

Talvez você tenha achado que, além de mentiroso, fui também excessivamente poético. Mas o que quer? Para o homem antigo, os mitos e os rituais são experiências concretas que ele compreende até em seu existir corporal e cotidiano. Para ele a realidade é uma unidade tão perfeita, que a emoção que sente, digamos, frente ao silêncio de um céu de verão, equivale totalmente à mais interior experiência pessoal de um homem moderno.

Metáfora para o processo de transformação histórica do homem ocidental, as três idades de Jasão culminam com a sua cegueira e a sua surdez para o mundo que the deu ossos 
e carne. O desaparecimento da porção besta, divina e extraordinária do centauro acusam Jasão de ter jogado para fora de sua história e de sua vista, irremediavelmente, o sagrado, o surpreendente, o extraordinário, a loucura, a pulsão dos instintos e do desejo, o sonho, o delírio, a fantasia. $E$ isso tudo teria ocorrido de forma tão radicalmente violenta na história do Ocidente que Pasolini acrescenta a esses três diálogos uma quarta cena, em que aparecem simultaneamente, para Jasão, o centauro em forma de centauro e o centauro deformado, livre de sua fração animal, no intuito de nos fazer perceber, através desta cena, que nem Jasão percebeu sua própria transformação. Seria este o sentido maior e mais trágico do seu desencontro: recalcado, ele realiza e encarna à perfeição o próprio esquecimento, porque é ele, inteiro e sozinho, todo o esquecimento daquele mundo antigo, mundo de Medeia. Só ele não percebeu a ruptura, só ele não percebeu que o centauro havia perdido sua parte animal. E é por isso que Jasão precisa ser lembrado do que sequer reconhece, assim como não reconhece o seu papel em toda essa história. A peça de Eurípides e o filme de Pasolini acodem-no ao lembrá-lo do que não deveria ter esquecido. Assim, nesta cena, avistando agora a dupla figura do centauro, a extraordinária e a ordinária, Jasão, surpreso, pergunta: "Ora, como é que vocês são dois?". E um deles responde: "Mas nós já tínhamos aparecido os dois para você". E Jasão, por fim: "Não notei". Ele não viu a perda do próprio centauro passar ante seus olhos, justamente os seus olhos, pois estão neles os motivos e as condições para que todo e qualquer centauro se desfaça de vez. Sim, a perda do centauro remete à perda desse sagrado arcaico, à perda do extraordinário, da magia e da natureza como uma potência tão divina quanto indomável; perdeu-se o encanto e a fantasia de uma criatura fabulosa, e toda a poesia que a acompanhava ao criá-la. Mas é necessário frisar, por ser absolutamente significativo, que a parte perdida, a parte que desfigura o centauro, é a parte da besta, é a potência, a fúria do cavalo; foi também isso que Jasão jogou fora, em nome de camadas e camadas de civilização que são necessárias, década a década, para se transformar num homem educado, bem comportado, que controla os seus instintos, que reprime os seus desejos e que se adequa neuroticamente aos padrões e ditames da opressão moral imposta pela sua própria cultura. Tudo isso em nome do pretenso "iluminismo" e luminosidade de uma razão que há sempre de decidir o que é melhor, inclusive a decisão de reprimir e violentar o próprio corpo para investir em sua alma, tornada agora um conceito vago, abstrato, metafísico e sem carne. Que distância para o mundo de Medeia, onde e quando os próprios deuses não transcendiam os limites da "carne", sendo eles mesmos um corpo, corpo do mundo. Jasão aposentou portanto a pele, a fúria, o instinto, e tudo isso significa o cavalo perdido. Se os antigos sacrifícios são vistos com horror pelo homem moderno, por que será que ele não se aterroriza com o sacrifício de uma besta mutilada pela metade, cujo resultado é ele mesmo? Não será essa a sua loucura e seu delírio, o delírio e a loucura de tanto cálculo, sanidade e pretensa "normalidade"?

Para Pasolini, se existe uma tragédia maior na história do Ocidente e no presente do homem contemporâneo, é a tragédia dessa perda, a tragédia desse que sangrou a si mesmo e nem o sabe mais. A tragédia de um tempo em que a própria tragédia foi 
expulsa, e com ela sua visão de mundo, sua fala, sua poesia. A tragédia, como gênero dramático e literatura, e, mais ainda, como visão de mundo e modo de existência, passa a ser impossível a partir do momento em que esses deuses se esfacelam, porque, uma vez esfacelados, as leis e potências que eles representam, dissipam-se, não restando mais como produzir o impasse e mesmo o absurdo da condição humana em contraste com a realidade natural e divina, contradição principal e êmulo maior do gênero trágico: sem impasse, irresolução e dilema, sem a impotência do humano ante a potência do divino não há o trágico. Daí sua insistente ambiguidade, que a pretensa clareza lógica e meridiana do discurso racionalista do homem moderno rechaça como incoerência, como simples contradição lógica.

Retomando a cena do (des)encontro de Jasão com os dois centauros, é extremamente precisa a decisão de Pasolini em fazer o novo centauro, aquele que já não é mais centauro, falar, enquanto o outro se mantém calado. Não é que este não fale mais. Talvez fale, sua voz, de algum modo, ainda ecoa. O espantoso, porém, é perceber que, ainda que ele diga o que puder e tiver a dizer, nossos ouvidos não mais o compreenderão, como se toda a sua fala fosse agora estéril diante daquele inteiro esquecimento, aquela inteira surdez que Jasão representa. $E$ no que resulta, concretamente, Jasão não mais conseguir ouvir essa voz? Resulta, por exemplo, na nossa incapacidade de lermos uma narrativa mítica hoje com um mínimo de intimidade e propriedade, com um mínimo de proximidade para com essa fala. Em geral, parte-se do princípio que essas vozes, no pior sentido infantis, já não têm nada a dizer. Basta lembrar, afinal, que a palavra "mito" é hoje empregada como sinônimo de falácia e mesmo mentira ${ }^{13}$, para que se reconheça toda a semântica de Jasão e o quanto o mito e sua poesia estão mortos para ele, assim como o seu modo de dizer e conceber o mundo e a vida. A palavra "mito" em grego significava, dentre outros sentidos afins, simplesmente "palavra". É mordazmente irônico vê-la, em nossa semântica atual, na condição de ser justamente a palavra que significa algo próximo a "palavra que não diz nada". Por isso o próprio elogio ao mito, como o faz genialmente Fernando Pessoa, precisa indicar o seu esvaziamento para enaltecê-lo: "O mito é o nada que é tudo". ${ }^{14}$ Por que só um contemporâneo, até para elogiar o mito, pode dizer - e talvez até deva dizer que ele é um nada? Porque também ele é esse homem moderno, contemporâneo, e viu, como Pasolini, essa voz se esvaziar, dissipada pelas vozes de Jasão. Mas Pessoa, em contrapartida, ao dizê-lo um nada que é tudo, parece advertir-nos de que esse nada é o nada da nossa surdez; parece dizer-nos, para que não nos enganemos, esse "nada" é tudo, essa voz é que fundou o homem. E a provocação aqui é: por mais e maiores que tenham sido os prodígios de Jasão, essa voz ecoa subterraneamente em nós, assim como o mundo de Medeia ainda constitui, mesmo que subterranemente, muitas camadas do nosso solo. E então, justamente isso que se aposentou, isso que há muito já não nos é contemporâneo, talvez nem mesmo a Eurípides, isso mesmo nos é, também, estranhamente próximo. Esse aspecto que matiza uma voz tragicamente muda e estranhamente ainda viva, também será postulado pela fala do centauro de Pasolini, quando, na cena de sua dupla aparição, o centauro que ainda pode falar a Jasão dirige- 
se a ele e o adverte: "Você não pode escapar completamente dele, ele faz parte da sua formação". Haveria assim um resíduo em nós, mesmo que inconsciente e irrefletido, dessa fundação. Um mundo soterrado por nós, nos é também um mundo subterrâneo ${ }^{15}$, que não nos deixa isentos dos seus tremores.

Em uma dessas conversas entre Jasão e Quíron, vê-se Pasolini retornar à critica quanto aos feitos e aos supostos ganhos obtidos por Jasão em sua evolução histórica. Em linhas gerais, o que o centauro tem a lhe dizer sobre o seu modo de raciocínio e de como este transfigurou o mundo, acusa-o de ter conseguido, além de desencanto, desenvolver um pensamento tão abstrato e mesmo metafísico, que o deus que sucedeu àqueles deuses antigos, "carne do mundo", resultou num deus suprassensível, como o é o deus cristão. Um deus suprassensível é também, forçosamente, um deus não-sensível, um deus distante, acessível talvez apenas pelo intelecto, como propõe e reconhece a própria teologia cristã. ${ }^{16} \mathrm{Em}$ seu intuito de enaltecê-lo, de fazê-lo superior, essa nova tradição tece um deus longínquo, para além - porque superior - de toda a natureza; um deus que não se pode sentir, não se pode ver, ouvir ou cheirar; um deus que, não tendo corpo, é pura razão; e sendo metafisicamente constituído, é também de todo imaterial, inatingível: um deus que também perdeu a sua fração de besta para poder ser o que é. A natureza e o caráter de um deus assim concebido exigem para ele uma teologia, uma ciência de deus. Sua "experiência" possível encontra-se na ordem do inteligível e, portanto, na ordem do intelecto. Ao passo que os deuses antigos, os deuses de Medeia e de Quíron, são ditos textualmente por Pasolini como "próximos", porque toda extensão do mundo é sensivelmente sagrada:

Tudo é sagrado. Tudo é sagrado. Tudo é sagrado. Não há nada de natural na natureza, meu pequeno. Guarde isso na memória. Quando a natureza lhe parecer natural, tudo terá acabado e começará qualquer coisa outra. Adeus céu, adeus mar. Que belo o céu! Próximo. Feliz. Diga, te parece mesmo que algum pedacinho dele seja natural e que não pertença a um deus? Assim como o mar, neste dia em que você completa treze anos, e pesca com os pés na água morna. Olhe atrás de você. O que vê? Talvez alguma coisa de natural? Não!

Esse outrora sagrado, tão naturalmente sagrado que faz da natureza algo impossivelmente natural, esse modo da divindade, sua fantasia, magia e tudo mais que Medeia representa, foi expulso por Jasão para bem longe, para literalmente o suprassensível, porque sendo superior ao sensível é, também, in-sensível, porque não sente, não cheira, não vê. Ele não tem onde e não tem quando, isso significa ser eterno, ser indeterminado; não ser físico, ser metafísico.

A esse respeito, é importante sublinhar um outro momento da fala de Quíron, em que ele mesmo "critica" o modo da sua narrativa: "É verdade, é uma história um pouco complicada, porque é feita de coisas, não de pensamentos". Talvez as sucessivas relações genealógicas de parentesco, que unem o homem a seus antepassados e à natureza divina e sacra que o cerca e inclui, exija ao ouvido de Jasão a estranheza de 
tantos nomes soltos, concretos, especificamente singulares e, por consequência, confusos, ao menos para Jasão, uma vez que resistem a serem reduzidos a padrões universais racionalmente ordenados. Para Medeia-Pasolini esse procedimento consiste numa odiosa simplificação da realidade, cujo fito final visa a gerar a ilusão de que a domamos, de que temos enfim domínio sobre ela. De qualquer modo, um tal procedimento opera uma profunda transfiguração do real e um novo alinhamento do homem em sua relação para com a natureza: transitando de indomável a domada, ela, a natureza (Medeia?), já não parece poder impor-se ao homem; fragilizada, é feita não mais do que recurso de sua própria técnica, ferramenta submissa à própria mão humana, que a instrumentaliza. Por isso Jasão, naquela cena, parece bem mais familiarizado com pensamentos mais abstratos, estruturais. $E$ foi de fato a partir de abstrações que ele extraiu a divindade da carne do mundo; extraiu-a da sensibilidade e destinou-a ao suprassensível, apartando-a da natureza. Trata-se de um modo de pensar que altera diametralmente a natureza de deus e, com isso, faz advir toda uma nova forma de estar e se comportar no mundo. Um deus de tal caráter acaba por favorecer, senão exigir, a autonomia da razão; o esquecimento e a repressão do corpo; a maldição da sensualidade; o constrangimento dos impulsos; e tantos outros gestos semelhantes que compõem a sua moral prevalecente.

Em contraste a esse deus sem pele ou carne, o corpo literalmente natural das divindades míticas faz com que "cada pedacinho" do cosmo seja sagrado. "Tudo é sagrado", exclama três vezes o centauro. Tudo, não apenas um. A troca do múltiplo pela unidade representa, igualmente, o favorecimento da ortodoxia em detrimento da heterodoxia e, com isso, a intensificação da intolerância e da intransigência, o acirramento dos ódios, arma fundamental para o impulso invasor e civilizatório praticado e alimentado historicamente pelo Ocidente.

E porque "tudo é sagrado", também "não há nada de natural na natureza". Será com a ciência que a natureza tornar-se-á natural, despida de sua sacralidade, desmitificada. É esse o processo que leva histórica e progressivamente ao desaparecimento dessas divindades. Os deuses estão mortos, suas vozes caladas. Nós o matamos ${ }^{17}$ :

Ali, conhecerá um mundo muito distante do uso da nossa razão. Como você poderá ver, a vida desse mundo é muito realista, porque só o que é mítico é realista, e tudo que é realista é mítico. Isso, pelo menos, é o que prevê esta nossa divina razão. O que ela não pode prever, infelizmente, são os erros aos quais conduzirá você. E quem sabe quantos serão! O que o homem, descobrindo a agricultura, viu nos cereais, o que aprendeu desta relação, o que compreendeu do exemplo das sementes, que perdem a forma debaixo da terra para renascer, tudo isso representou a lição definitiva, a ressurreição, meu caro. Mas agora essa lição definitiva já não serve mais. O que você vê nos cereais, o que entende do renascer das sementes, para você agora não tem mais nenhum significado, como uma remota recordação que já não lhe diz mais respeito. De fato, não existe nenhum deus.

A questão para Pasolini, nesse cruzamento de realidades entre o antigo e o moderno, 
mundos distintos por operarem segundo um modo de pensamento e linguagem igualmente distintos, toca também a necessidade de ponderar qual deles forjou o mundo mais sedutor. Com que palavras e pensamentos se viveu melhor sobre a Terra? $\mathrm{O}$ mundo que mantinha, vivia e admirava a nossa divina porção besta, ou aquele que pretendeu e pretende continuamente depurar-se dela? Ainda que estas perguntas sejam claramente pertinentes, pelo quanto excitam a reflexão, talvez sejam igualmente impossíveis de responder a contento. Talvez. No caso de Pasolini, contudo, a tomada de posição é clara: ele prefere, bravamente, o mundo bestial. O sentido do processo civilizatório do Ocidente consiste numa depuração insistente e sistemática das potências agora vistas como bárbaras e selvagens. A pretensa "desbestialização" do homem resulta, paradoxal e ironicamente, numa história de violência e opressão, em que sobejam guerras e derramamento de sangue. A civilização é a própria barbárie, quando refletida no espelho que ela recusa a mirar, mas no qual Pasolini insiste em fazê-la refletir.

\section{Extras: reprodução das falas de Quíron, o centauro, a Jasão}

\section{Quando Jasão possui apenas cinco anos}

Hoje você completa cinco anos e vou lhe dizer a verdade: você não é meu filho. Não o encontrei no mar. Foi tudo mentira o que lhe contei. Você não é mentiroso, mas eu sou. Me diverte contar mentiras. Você fica triste de saber que não é meu filho, que eu não sou nem seu pai nem sua mãe? Tudo começou por causa de um carneiro com pele de ouro. Sim, de um carneiro que falava, que era divino. Zeus o tinha dado a Néfele, aquela que rege as nuvens, porque Néfele tinha de salvar os seus filhos. Tinha que salvá-los porque Ino queria matá-los. Ino era filha de Cadmo e segunda mulher do rei dos Orcomenos, que se chamava Atamante. Atamante era filho de Éolo, aquele que rege os ventos, do qual, antes, Ino havia sido esposa. Bem, foi apenas uma questão de ciúmes. O carneiro do qual Ihe falei, que tinha a pele de ouro, conseguiu levar para além-mar um dos dois filhos de Néfele, que se chamava Frixo. Ele chegou na cidade do rei Éetes, que era filho do Sol. Este rei acolheu Frixo e sacrificou ao deus Zeus o carneiro com a pele de ouro, para agradecer-lhe. Os descendentes de Éolo fizeram tudo para reconquistar aquele velocino, porque dava sorte aos reis. Garantia que o reino deles jamais acabaria e que tudo ficaria sempre como antes. Fizeram de tudo, mas não conseguiram. Não conseguiram! E você, filhote, é um descendente de Éolo, porque é filho de um filho daquele Atamante de que te falei antes, e que era rei de lolco, uma cidade vizinha daqui, muito rica em ovelhas e em grãos, que são propriedade do rei. Seu tio Pélias mandou prender o seu pai e se apossou do reino, que é seu por direito, e eu fiquei com você aqui, em segurança. Entendeu? É verdade, é uma história um pouco complicada, porque é feita de coisas e não de pensamentos.

Quando Jasão já conta com treze anos de idade

Tudo é sagrado. Tudo é sagrado. Tudo é sagrado. Não há nada de natural na natureza, 
meu pequeno. Guarde isso na memória. Quando a natureza the parecer natural, tudo terá acabado e começará qualquer coisa outra. Adeus céu, adeus mar. Que belo o céu! Próximo. Feliz. Diga, te parece mesmo que algum pedacinho dele seja natural e que não pertença a um deus? Assim como o mar, neste dia em que você completa treze anos, e pesca com os pés na água morna. Olhe atrás de você. O que vê? Talvez alguma coisa de natural? Não! É uma aparição o que você vê atrás de você. Como as nuvens que se espelham na água parada, pesada, das três da tarde. Olhe lá longe aquela tira negra sobre o mar, brilhante como o azeite. Aquelas sombras de árvores e aqueles canaviais. Em cada ponto que seus olhos veem, está escondido um deus. E se por acaso não está, aí deixou sinais de sua presença sagrada. Ou silêncio, ou cheiro de erva, ou frescor de água doce. Sim, tudo é santo, mas a santidade traz consigo uma maldição. Os deuses que amam também odeiam.

\section{Quando Quíron já não é mais um centauro e Jasão já é um homem adulto}

Talvez você tenha achado que, além de mentiroso, fui também excessivamente poético. Mas o que quer? Para o homem antigo, os mitos e os rituais são experiências concretas que ele compreende até em seu existir corporal e cotidiano. Para ele a realidade é uma unidade tão perfeita, que a emoção que sente, digamos, frente ao silêncio de um céu de verão equivale totalmente à mais interior experiência pessoal de um homem moderno. Você irá até seu tio, usurpador do seu reino, para reclamar os seus direitos. E ele, para te eliminar, precisará de algum pretexto. Poderá te mandar realizar alguma missão, como a reconquista do velo de ouro, por exemplo, e assim você irá para um país distante, além-mar. Ali, conhecerá um mundo muito distante do uso da nossa razão. Como você poderá ver, a vida desse mundo é muito realista, porque só o que é mítico é realista, e tudo que é realista é mítico. Isso, pelo menos, é o que prevê esta nossa divina razão. 0 que ela não pode prever, infelizmente, são os erros aos quais conduzirá você. $E$ quem sabe quantos serão! O que o homem, descobrindo a agricultura, viu nos cereais, o que aprendeu desta relação, o que compreendeu do exemplo das sementes, que perdem a forma debaixo da terra para renascer, tudo isso representou a lição definitiva, a ressurreição, meu caro. Mas agora essa lição definitiva já não serve mais. O que você vê nos cereais, o que entende do renascer das sementes, para você agora não tem mais nenhum significado, como uma remota recordação que já não the diz mais respeito. De fato, não existe nenhum deus.

\footnotetext{
* Alexandre Costa é professor adjunto do Departamento de Filosofia da UFF.

${ }^{1}$ ADORNO, T.; HORKHEIMER, M. Dialética do esclarecimento. Rio de Janeiro: Jorge Zahar Editor, 1988.

${ }^{2}$ Edipo $\operatorname{Re}(1967)$ e Medea (1969).

${ }^{3} \mathrm{O}$ uso do termo "homem", incluso na expressão acima empregada, alude aqui não apenas a seu caráter geral - indicando a espécie humana, tal como é comum à maioria das línguas igualmente
} 
ocidentais -, mas também e ainda mais especificamente ao masculino, uma vez que o ideal civilizatório a que me refiro vem a ser, talvez, o principal reflexo da história do Ocidente como cultura patriarcal. O desenvolvimento das minhas considerações ao longo deste ensaio busca demonstrar o quanto a figura de Jasão constitui uma imagem-símbolo desse patriarcado e do processo sócio-cultural que permitiu a sua fundação e consolidação históricas. Deste modo, o emprego do termo "homem" neste escrito obedece, desde o seu título à sua palavra final, a esta perspectiva.

${ }^{4} \mathrm{Ou}$, como bem expressou Walter Benjamin, em suas teses Sobre o conceito de história: "Pois todos os bens culturais que ele vê têm uma origem sobre a qual ele não pode refletir sem horror. Devem sua existência não somente ao esforço dos grandes gênios que os criaram como à corveia anônima dos seus contemporâneos. Nunca houve um monumento da cultura que não fosse também um monumento da barbárie. $E$, assim como a cultura não é isenta de barbárie, não o é tampouco, o processo de transmissão da cultura [...] O assombro com o fato de que os episódios que vivemos no século XX 'ainda' sejam possíveis não é um assombro filosófico. Ele não gera nenhum conhecimento, a não ser o conhecimento de que a concepção de história da qual emana semelhante assombro é insustentável". Grifo meu. BENJAMIN, W. "Sobre o conceito de História". In: Magia e técnica, arte e política: ensaios sobre literatura e história da cultura. São Paulo: Brasiliense, 1994. Disposição semelhante mantém Marcuse, ao apontar essa mesma dialética a que me refiro, defendendo a ideia de que civilizar é barbarizar. Cf. MARCUSE, H. Eros e civilização: uma interpretação filosófica do pensamento de Freud. Rio de Janeiro: Zahar, 1968.

${ }^{5}$ O termo "diabólico" é de origem grega e nada a tem a ver, inicialmente, com a sua atual designação, que o correlaciona ao célebre personagem do ideário cristão. Trata-se do antônimo exato de "simbólico": diabolizar significa originalmente algo como "decifrar; desmontar o símbolo". Assim, a narrativa mítica, essencialmente simbólica e alegórica, vem a ser diabolizada quando decifrada parte à parte, desmembrada em seus elementos constitutivos que, separados e discriminados (em grego: criticados), prometem maior domínio sobre eles; o mesmo sentido guarda, no grego original, o termo "dialética", que remete à ideia, ou necessidade, de "dividir, despedaçar o discurso", a fim de contemplar sua constituição, estrutura e eventuais fragilidades ou lacunas. Em ambos os casos, reconhece-se a operação de um pensamento e de um modo de linguagem de cunho analítico e hermenêutico.

${ }^{6}$ A esse respeito, indico a leitura do excurso "Ulisses ou mito e esclarecimento". In: ADORNO, T.; HORKHEIMER, M. Op. cit., pp. 47-70.

${ }^{7}$ Aludo especificamente à cena em que Jasão já não consegue ver o centauro Quíron, seu preceptor, como centauro, mas apenas como um homem tal como ele, Jasão; um homem "livre" de sua parte animal, "livre" de sua fração cavalo. É importante notar que é o olhar de Jasão que subtrai a parte animal ao centauro, sendo essa metamorfose fruto e efeito da cegueira de Jasão, da impotência do seu olhar, que já não reconhece nem o mágico, nem o fantástico, nem a pulsão dos instintos como lugares convenientes ao "novo homem".

${ }^{8}$ Julgo importante alertar que uma crítica à razão ou à racionalidade, gesto muito característico da arte e da filosofia contemporâneas, não deve ser compreendida nem exercitada na ordem de uma demonização da razão, como se ela, em si mesma, fosse algo a combater. Trata-se justamente de criticar não a razão e a racionalidade em si, elementos constitutivos do humano, mas sim a sua desmedida, a sua hipertrofia histórica, estas sim, responsáveis pela demonização, castigo e marginalização de tudo aquilo que não lhes tenha parecido racional e razoável. Uma crítica à "razão" deve ser compreendida, aqui, portanto, como uma crítica ao racionalismo e a essa hipertrofia, redundando igualmente em apontar os limites da própria racionalidade, fazendo ver que aquilo que the escapa - a desrazão, o arracional ou simplesmente aquilo de que não é possível obter compreensão na ordem do entendimento e do raciocínio - é igualmente constitutivo do humano e exige não só o seu reconhecimento como o seu devido lugar na fruição da existência, em vez de ser sistematicamente reprimido e asfixiado por normas da cultura que lhe são franca e violentamente hostis. 
${ }^{9}$ É relevante frisar que Pasolini toma o cuidado de manter essas informações da origem regional de Medeia intactas em seu filme, por reconhecer nelas elementos importantes na composição do seu pretenso barbarismo.

${ }^{10}$ Cf. NIETZSCHE, F. O nascimento da tragédia. São Paulo: Cia. das Letras, 1992.

${ }^{11}$ O exemplo máximo da arrogância e mesmo desprezo de Jasão ante tudo o que Medeia possa representar destaca-se, no filme, por uma fala de Medeia que será respondida da forma mais soberba possível por seu amado odiado Jasão. Após saber que seria preterida, Medeia procura Jasão e tenta convencê-lo a seguir com ela, mantendo a sua própria palavra. Diante da resistência de Jasão, ela suspira "mas eu te dei tudo", em clara alusão ao fato de os sucessos de Jasão terem sido todos promovidos por ela: com efeito, foi Medeia e não Jasão que conseguiu obter o velo de ouro, pois é justamente ela quem realiza todos os prodígios mágicos indispensáveis tanto à conquista, como à fuga; é ela, ainda, quem mata os inimigos de Jasão. Ainda assim, em pleno esquecimento de tudo isso, ou por lhe faltar realmente a condição de reconhecer valor em todos esses atos, ele responde àquele suspiro, afirmando: "mas o que você me fez foi pouco, eu fiz muito mais por você do que você por mim.". E o que teria feito Jasão por Medeia? Talvez ele respondesse: "Eu te helenizei, eu te trouxe para a Grécia que é mesmo Grécia, agora você tem modos, comporta-se bem e civilizadamente". É assim que Jasão civiliza Medeia, que vai, portanto, morrendo ao seu lado, tal como este novo mundo, que ele representa, apaga aquele em que Medeias são seres possíveis.

${ }^{12} \mathrm{~A}$ íntegra desses diálogos está apresentada ao fim deste ensaio.

${ }^{13} \mathrm{Em}$ uma das falas do centauro a Jasão, ouve-se: "Hoje você completa cinco anos e vou lhe dizer a verdade, você não é meu filho, não o encontrei no mar, foi tudo mentira; foi tudo mentira o que Ihe contei, você não é mentiroso, mas eu sou, me diverte contar mentiras, você fica triste de saber que não é meu filho, que eu não sou nem seu pai, nem a sua mãe? Tudo começou por causa de um carneiro com pele de ouro, sim, de um carneiro que falava, ele era divino...".

${ }^{14}$ PESSOA, F. "Ulysses". In: Mensagem.

${ }^{15}$ É inegável a influência dos escritos de Freud sobre as reflexões de Pasolini durante a sua ocupação com a tragédia grega, principalmente realçada em seu Edipo Rei (1967), mas igualmente presente, como se vê, em Medeia. A esse respeito, o clássico Totem e tabu parece ter sido, dos textos freudianos, a leitura mais decisiva e cara a Pasolini.

${ }^{16}$ Lembre-se, a esse propósito, a célebre teoria da iluminação formulada por Santo Agostinho.

${ }^{17}$ Menção implícita ao "Monólogo do homem louco". Cf. NIETZSCHE, F. A gaia ciência. São Paulo: Cia. das Letras, 2001, III, 125, pp. 147ss. 